\title{
A Research on Factors of Forex Procedures in Private Bank
}

\author{
William Robert P, R. Monisha
}

\begin{abstract}
Considering the perception of the respondents the study was conducted on factors influencing forex procedures in a private bank. This study focus on the objective such as employees and customer knowledge in forex procedures and collect the respondents profile and also to find out the factors which influencing forex procedures. To achieve these Descriptive analysis style is employed, during this study the source of information is collected based on the self structured questionnaire from Reserve Bank of India guidelines. Frequency analysis, factor analysis and mean analysis was used to analyze the collected information. The study inferred that majority of respondents are male within the age group of 25 to 35 years and designation with middle level.The finding of the study revealed that Ofac form, Realization of overseas, Merchant rate transaction are the factor which influencing the Forex procedures
\end{abstract}

Keywords: Foreign exchange procedures, Office of foreign assets control(ofac), Realization of overseas, Merchant trade transaction, Self write off, Factor influencing the procedures.

\section{INTRODUCTION}

Foreign Exchange(FOREX) is like swap of country's currency(cy) into other country's currency value established by other country government. The exchange rates tells how much the country's CY is benefit in the currency FOREX of the value being owed to get the currency. Export and import within the FOREX helps to extend the financial gain of the country. Export is a function of trading of good produced in one country are sold to some other country's for sale and the sale of the goods increases nations gross output. On the other imports represents bringing of foreign goods in another country where the products will be used are sold. Export and import are important element in balance of trade in the country, as lower the imports balance of trade will be positive and increase in import levels will have trade deficit. The private bank undertake purchase and sale transaction behalf of the customer and provides the service .The bank follows the rules and regulation of reserve bank of india for exporting and importing of goods .Some of the rules like an exporters can claim incentives for export if it gets a certificate from the bank. Also if the exporting person give form describing export later than 21 days bank be allowed to deal without any approval RBI, if the reason is acceptable for the delay. The objectives of the study is to seek out out the staff and client in forex procedures. To find out the demographic profile of the employees and customers in

\footnotetext{
Revised Manuscript Received on September 10, 2019.

William Robert.P, Asst. Professor, Saveetha School of Management, SIMATS, Chennai , Tamil Nadu, India.

(Email: William29robert@gmail.com)

R.Monisha, Student, Saveetha School of Management, SIMATS, Chennai, Tamil Nadu, India.

(Email: monmonisha1997@gmail.com)
}

forex and also to determine the factor influencing foreign exchange procedures. Through this analysis and comparison the bank workers would like to own a clear understanding of procedures which can facilitate educate their customers in exportation and clearing of bills etc .

\section{REVIEW OF LITERATURE}

Kumcu, E., et al., (1995). In his paper study the importance of export which leads to increase in company growth potential. As there is a sufficient export financial assistant program and managers knowing of those programmes motivate for success of export development strategies. The findings shows that level of export exploration, export interest and company size have the next instructive power on awareness than different company characteristics. Management of non mercantilism corporations considers the government export incentive negligent for the future export activity interest of the managers .

Rai, K., and Bhanumurthy, N. R. (2004) inspected FII in India it had exceeded US $\$ 12$ billion. Their impact on domestic market by the large volume of flows. In order to liberalize the capital account understanding of behavior of flows is important. FII flow lean on securities make a return, increasing rates and extant risk. Future risk and stock exchange returns are final of FII inflows. In this research not found any cause and effect relationship link from FII and stock returns by maintaining the volatility in stock market and reducing the ex-ante risk helps in bringing increase FII and positive impact on the economy.

Marshall, A., and Weetman, P. (2007) Managers select to not admit data within their management in the financial plan, there's associate information difference between the managers and end users and therefore deficient of clarity. A sharing on information between the managers, users are found out by questionnaire responses.US and UK samples were collected and founded there is incomplete disclosure of information.the model says that

complete disclosure of accounting in an international framework must be adequately adjustable to furnish differences in national managerial behavior.

Kljucnikov, A., \& Popesko, B. (2017) The Export Orientation of SMEs important associate of the enterprises' competing ability. The aspiration of this study is to outline also assess admissible path of executive for export funding and EX activities, with respect to the brunt of the chosen socioeconomic element. The investigation of Slovak 
business encompassing controlled in 2016 was evaluated by the apparatuses of graphic insights, just as rates and midpoints, rotate tables, as an activity of separating and derivation, Pearson's chi-square measurements at five-hitter hugeness level. The consequences of Slovak business people counsel mostly given their administrations, item to the residential market, though their fare likely shut and pessimistic.

Berganza, J. C., and Broto, C. (2012) potential economies with (IT) swelling objective set by the administration face a trouble between satisfying the hypothetical states of exacting IT, which infer completely adaptable swapping scale which bring out genuine oversaw skimming conversion standard with FOREX impedance in impartial swapping scale unpredictability. Cross-sectional time arrangement information is utilized and established swelling targets drive to higher swapping scale precariousness. The mediation of outside trade in some IT nations had been dynamic to diminish instability than in non-it nations.

Yazid, A. S., and Muda, M. S. (2006). Mentioned that monetary disaster happened on 1997 September to 1998 August, many Malaysian multinationals suffered badly for result of fluctuations in FOREX. Thus, overseas danger administration has appeared in the emerging market Malaysian multinational it considers the cause of risk managing and length of management manipulate and foreign trade danger management of documentation. Finding shows that the mass multinationals concentrated on administration things and routine reporting on spin off activities. The top management takes care on the financial losses associated with by- product trading .

Pritamani, M. D et al., (2004) The available literature reports are unimportant total exposure for mercantilism companies, whenever total exposure assimilate every specific firm effects economic. A dual-effect hypothesis is used with the prepared hypothesis. Companies are distress between domestic economy and foreign markets. These effects a minimum of partly compensate for exporters and add on for importers. It is forecast ed positive exposure for importers and less on exporters. The study recommended equally weighted portfolio closely on domestic companies.

Ho, K. W. (1993) The investigation discovers the expanded change in remote trade advertise as of late has expanded the swapping scale hazard looked by the organizations. There has no spectacular foreign exchange loss in Singapore this is due to risk free approach adopted by the Singapore companies for foreign exchange uncertainty management. The study delved with the general practiced adopted by listed companies in Singapore. FOREX risk management is one of the important operation in listed companies. The result of the study shows more of the company adopt a centralized approach in which various task of treasuries are centrally managed by a head office team. While other responding companies conclude that they operate the treasury as cost the result of the study shows that a number of the businesses are able to take risk exploit some of their exposure not protected from loss.the companies also uses hedging techniques and also currency options and future options are not widely used and majority of the responding companies do not measure performance of the treasury function.
Schanz, J. F. (2009) The study provided how the foreign exchange settlement influence the risk financial groups adopts a wide range approaches for liquidity risk management in local liquidity management the subsidiary financial group maintain separate pool of liquidity in their local currency to meet the obligation of funds domestically there are many barriers in managing liquidity globally.Delayed settlement of currency is the main issue and bank failure to execute payment may affect the liquidity outflow. The result of the study is to have better coordination of FOREX settlements for offsetting effects on risk.

Belk, P. A. (2002)The study conferred the results obtained from 3 coexisting research organized with global companies within the United States of America and European nation and Germany. It concentrated on the association of hazard the board of outside trade particularly the target of trade chance administration. The unification of decisive characteristics of the choice of manufacturers one self. While bearing in mind the pressure of the survey technique, the need restricted the dimensions of every of the 3 samples, the results provide acceptance of the risk-averse character of multinationals, the impact of size on centralization of deciding, and therefore the generality of the money handler as a choice maker.

Ahmed, H. An., and Uddin, M. G. S. (2009) This examination analyzes the easy going nexus between fare, import, abatement and worth increment for Bangladesh exploitation yearly records from 1976 to 2005. This paper makes use of your time series political economy instrumentality to seem into the connection as well as import and remission within the model

Study indicates limited help in choose of export-led boom hypothesis for Bangladesh. Export and remittance motive GDP increase in the quick run and does now not have any lengthy run influence. GDP, on the other hand, causes export increase in the lengthy run. Import does now not have any effect on GDP or export growth.

Acording to Bhaskaran, P. B., and Priyan, P. K. (2015). In their paper expressed that New organizations in India are getting to be worldwide in their tasks - through imports and fares, by fitting assembling plants abroad and by means of joint-adventures. All through this strategy the vast majority of them territory unit taking care of different monetary forms. This had expanded the general introduction of Indian organizations to remote conversion scale changes. In this manner, to look at the creators have drawn for the situation investigate procedure. The creators considered sixty-four cases for this reason. The examination concentrated on Indian organizations from parts like Textiles, IT, Gems and gem dealers, Pharmacy, Engineering, FMCG and Energy. Their plan of action their arrangements and strategies for overseeing introduction of hazard in Forex . The creators have attempted to recognize the natural variables fundamental the Forex introduction and to spot designs, assuming any, at interim the adapting technique and completed that the bits of knowledge would advance figure

Published By: 
a conventional system.

Banga, R. (2006). The paper focus on the export extend and their effect on remote direct speculation (FDI) all through a creating nation. FDI may end in fare enhancement at interims the host nation If it totally changes the fare force of businesses that have a low share in world fares. FDI may be encouraged Indirectly over export diversity through spill over effects. The existence of FDI associate business may adds the export intensity of home companies. The result shows FDI from united states as increased Indian export and other countries like Japanese investment direct not have much impact on Indian exports.

Sekkat, K., \& Varoudakis, A. (2000) Empirically determined the impact of charge per unit guidelines on store-bought export act on a panel of extensive African desert . They examined impact of charge per unit policy over the after effects of 3 pointers: genuine powerful charge per unit (REER) changes, genuine charge per unit (RER) unpredictability, and (model-based proportions of) RER situation. Fare supply condition for scaling the units. The delivering areas (material, synthetics, and metals) and an attempt of charge for each unit systems: a precarious and quick rate system portray by about six CFA nations and a further adaptable rate system diagram by 5 non-CFA nations The findings recommend that charge per unit management matters for performance of export and impact the changes among the REER and by the adverse influence exerted severally by RER placement.

Hermann Hesse H. (2009) 1950 countries had concerned field in primary market this element steadily decreases with the buying power of primary exports and decreased growth, and expanding out of primary product into manufactures has been a significant policy goal of developing countries. New in queried relating to export diversification have appeared among the recent literature and with necessary policy indication. The natural structural of structure outcome of the growth technique countries further growth through active considerations to changing exports. The market failures that cause personal under investment in efforts to reach new export markets or is it associated with different market failures The countries policies which the best suitable push diversification In order to increase export with main characteristic are used to expand policy to push diversification.

\section{RESEARCH METHODOLOGY}

This study used descriptive design .The data is gathered based on the self structured questionnaire from Reserve Bank of India guidelines from the clients and employees of Axis bank in Chennai .The Sample size used is 50 and the technique adopted is Convenience technique . Percentage, Mean and Factor analysis tools are used.

\section{DATA ANALYSIS}

TABLE NO-1

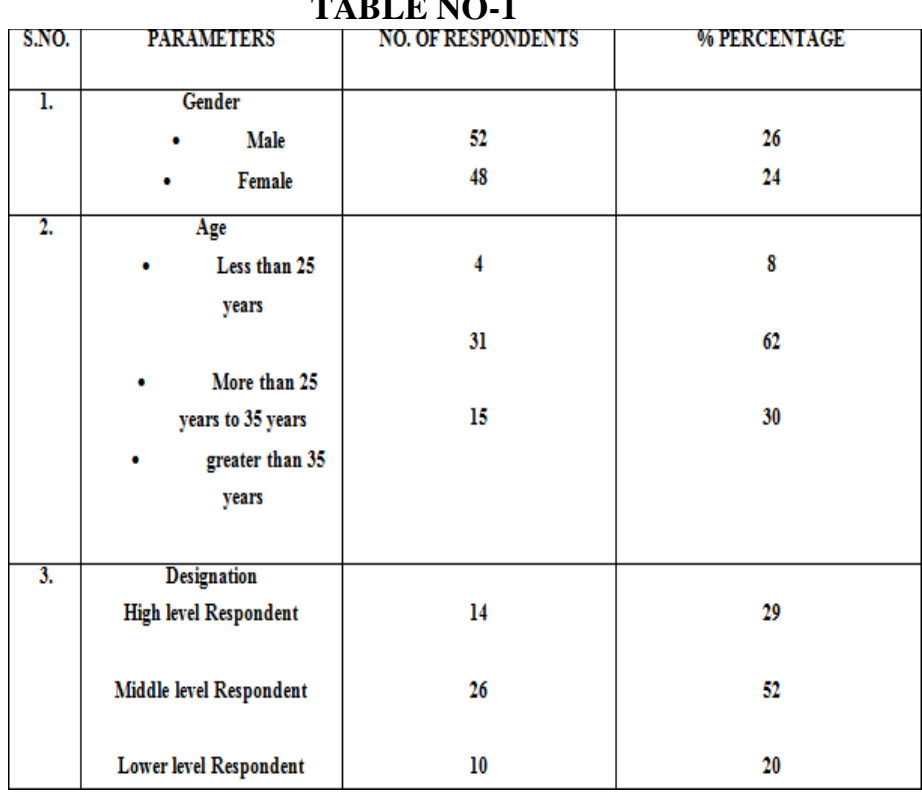

\section{Interpretation:}

The table no 1 shows that frequency analysis of gender ,Age and Designation. From the table it is inferred that majority of the clients are Male (52\%). The respondents at the age group of more than 25 to35 years (62\%) and most of the clients at the designation of Middle level Respondent $(52 \%)$.

TABLE NO-2MEAN ANALYSIS

\begin{tabular}{|c|c|c|c|}
\hline $\begin{array}{c}\text { S.N } \\
\text { O }\end{array}$ & $\begin{array}{c}\text { LEVEL OF } \\
\text { PERCEPTION OF } \\
\text { FOREX } \\
\text { PROCEDURE }\end{array}$ & $\begin{array}{c}\text { MEAN } \\
\text { VALUE }\end{array}$ & RANK \\
\hline 1. & OFAC Form & 3.90 & $\mathbf{9}$ \\
\hline 2. & Export Realization & 4.38 & $\mathbf{3}$ \\
\hline 3. & $\begin{array}{c}\text { Follow up of Export } \\
\text { Bill }\end{array}$ & 5.0 & $\mathbf{1}$ \\
\hline 4. & Realization of Overseas & 4.26 & $\mathbf{4}$ \\
\hline 5. & Softex Form & 4.12 & $\mathbf{8}$ \\
\hline 6. & Bill of Entry & 4.42 & $\mathbf{2}$ \\
\hline 7. & Export Documents & 4.16 & $\mathbf{7}$ \\
\hline 8. & Consignment Export & 4.20 & $\mathbf{6}$ \\
\hline 9. & $\begin{array}{c}\text { Merchant Trade } \\
\text { Transaction }\end{array}$ & 4.26 & $\mathbf{5}$ \\
\hline 10. & Write Off & 3.06 & $\mathbf{1 0}$ \\
\hline
\end{tabular}

\section{Interpretation:}

The table no 2 shows the mean analysis of perception of FOREX procedure it is clear that the variable follow up of export bill has the highest mean value (HMV) of (5.0) continued by variable bill of entry has the second HMV of (4.42). Followed that variable export realization has the mean value of (4.38). Pursued that variable realization of overseas has the mean value of realization of overseas has the (MV) of (4.26) proceeded by variable merchant trade transaction has the MV of (4.26). Pursued by the variable 
consignment export has the mean estimation of (4.20).Followed by the variable export reports has the mean pace of (4.16).Followed that variable SOFTEX form has the mean analysis of(4.12)followed that variable OFAC form has the mean value of (3.90) .Followed that variable write off has the mean value of (3.06).

\section{FACTOR ANALYSIS}

Table no-3 Analysis of Kaiser-Meyer-Olkin and Bartlett's test(KMO)

\begin{tabular}{|c|c|}
\hline \multicolumn{2}{|c|}{ KMO AND BARTLETT'S TEST } \\
\hline $\begin{array}{c}\text { Kaiser-Meyer-Olkin Measure of Sampling } \\
\text { Adequacy. }\end{array}$ & .618 \\
\hline $\begin{array}{c}\text { Bartlett's Test of Sphericity Approx. Chi-Square } \\
\text { Degrees of Freedom } \\
\text { Significant Value }\end{array}$ & $\begin{array}{c}154.368 \\
45\end{array}$ \\
\hline & .000 \\
\hline
\end{tabular}

\section{Interpretation}

The table no 3 shows the kmo analysis that majority have aware of Forex Procedures .The kmo worth ought to be more prominent than 0.5 and the significance worth ought to be 0.000these test measures the data sufficiency

\section{Analysis of Rotated Sum of Square}

TABLE NO-4 Analysis of Rotated Sums of Square

\begin{tabular}{|c|c|c|c|c|}
\hline \multicolumn{5}{|c|}{ Units } \\
\hline 5.10 & CONPONEITS & TOTAL & 90F VARIAICE & CUMMLATIVE \% \\
\hline l. & Component 1 & 2532 & 25,324 & 25,324 \\
\hline 2 & Component ? & 20.028 & 20,283 & 45.607 \\
\hline 3. & Component 3 & 1.804 & 18,044 & 63.651 \\
\hline
\end{tabular}

Interpretation-

The Table no 4 explains the components of variance that variables have been segregated into 3 factors. Those 3 factors collectively explains $63.651 \%$ of variables .

\section{Analysis of Rotated Component Matrix}

TABLE NO 5 - Analysis of Rotated Component Matrix

\begin{tabular}{|c|c|c|c|c|}
\hline S.NO & COMPONENTS & 1 & 2 & 3 \\
\hline 1 & $\begin{array}{l}\text { The beginning up companies can understand the } \\
\text { receivables of its abroad auxiliary and repatriate } \\
\text { through online payment gateway } \\
\text { service(opgs).(realization of overseas) }\end{array}$ & .830 & & \\
\hline 2 & $\begin{array}{l}\text { The exporters will deliver bill of passage in a period of } \\
\text { one month of re-imported of the traded thing from India } \\
\text { for granting export declaration form (edf) approval.(bill } \\
\text { of entry) }\end{array}$ & .757 & & \\
\hline 3 & $\begin{array}{l}\text { AD Bank allowing customers to do a third party } \\
\text { transaction in a Export Realization if Payment is } \\
\text { received from a Third party.(export realization) }\end{array}$ & .743 & & \\
\hline 4 & $\begin{array}{l}\text { In consignment export of good during the time of } \\
\text { forwarding the delivery archive to his abroad branch } \\
\text { ought to train them to convey them just against trust } \\
\text { receipt (consignment export) }\end{array}$ & .666 & & \\
\hline 5 & $\begin{array}{l}\text { Is AD Bank following and Aware about the Compliance } \\
\text { and Regulations of the OFAC (Caution listed)Countries } \\
\text { (ofac form) }\end{array}$ & & .719 & \\
\hline
\end{tabular}




\begin{tabular}{|c|c|c|c|}
\hline 6 & $\begin{array}{l}\text { Follow up of Export Bills for advance received against } \\
\text { Exports from AD Bank has been Carried out every } \\
\text { month.- Is letters and reminders sent from AD Bank. } \\
\text { (follow up of export bill) }\end{array}$ & .704 & \\
\hline 7. & $\begin{array}{l}\text { A typical SOFTEX structure has been conceived to } \\
\text { pronounce just as bulk export of software's,and the } \\
\text { exporters need to give data pretty much all solicitations } \\
\text { including the ones lesser than US\$25000. (soft ex form) }\end{array}$ & .680 & \\
\hline 8. & $\begin{array}{l}\text { Self give up by an exporter will be } 10 \% \text { of the estimation } \\
\text { of complete percentage continues acknowledged during } \\
\text { the past schedule year.(write off) }\end{array}$ & .594 & \\
\hline 9. & $\begin{array}{l}\text { Entire merchant trade transaction should be completed } \\
\text { within } 9 \text { months and there should not be any } \\
\text { disbursement of above } 4 \text { months(merchant trade } \\
\text { transaction) }\end{array}$ & & .906 \\
\hline 10. & $\begin{array}{l}\text { If delay in presenting export documents } 21 \text { days later } \\
\text { from date of export they shall provide reasons for delay } \\
\text { to the bank.(export documents) }\end{array}$ & & .849 \\
\hline
\end{tabular}

\section{Interpretation:}

It is clear from the table no5 that variable such as realization of overseas, bill of entry ,export realization , and consignment export are grouped into factor 1 and the factor is named as realization of overseas. variables such as Ofac form ,follow up of export bill, softex form are grouped into factor 2. And the factor is named as Ofac form. Variables such as merchant trade transaction, write off are grouped into factor 3 and the factor is named as merchant trade transaction.

\section{DISCUSSION \& RESULTS}

From the 10 factors it is reduced to 3 factors such as OFAC form, Merchant rate transaction and realization of Overseas based on the factor analysis. Also the kmo value is .618 and total variance explains $63.651 \%$. The variables are grouped into three factors is influencing the Respondents perception of Forex Procedures are OFAC form, Merchant rate transaction and realization of Overseas.

\section{CONCLUSION}

A FOREX bank which interchange foreign currency into local currency vice versa by carrying out this banks gets a part of commission for such transaction. The study about the employees and customer Perception of Forex procedure at Private Bank is found that most of the employees are middle level managers within 25 to 35 years in age group . The employees and customers are following the advance received against the exports.

The factor influencing the perception of Forex procedures are identified using factor analysis. It is found that the KMO value is greater than 0.5 and significant. The 3 factors identified which collectively explains $63.651 \%$ of variables.

The factors which is influencing the employees and customers perception of FOREX Procedures are OFAC form, Merchant rate transaction and realization of Overseas. The study shows the importance of self write off by the exporter in the case where the bill is delayed more than a year leads to the closure of the exporter account after seeing the previous year export and the payment made to the bank. Also majority of the respondents are unaware about the percentage of the self write off of the exporter. So they have to be educated about OFAC form, Merchant rate transaction and self write-off by the exporter.

\section{REFERENCES}

1. Kumcu, Erdoğan, Talha Harcar, and M. Ercan Kumcu. "Managerial perceptions of the adequacy of export incentive programs: Implications for export-led economic development policy." Journal of Business Research 32.2 (1995): 163-174.

2. Abor, J. Y., Agbloyor, E. K., \& Kuipo, R. (2014). Bank finance and export activities of Small and Medium Enterprises. Review of Development Finance, 4(2), 97103.

3. Rai, K., \& Bhanumurthy, N. R. (2004). Determinants of foreign institutional investment in India: The role of return, risk, and inflation. The Developing Economies, 42(4), 479-493.

4. Hassan Al-Tamimi, H. A., \& Mohammed Al-Mazrooei, F. (2007). Banks' risk management: a comparison study 
of UAE national and foreign banks. The Journal of Risk Finance, 8(4), 394-409.)

5. Marshall, A., \& Weetman, P. (2007). Modelling transparency in disclosure: the case of foreign exchange risk management. Journal of Business Finance \& Accounting, 34(5-6), 705-739.

6. Ključnikov, A., \& Popesko, B. (2017). Export and its financing in the SME segment. Case study from Slovakia. Journal of Competitiveness, 9(1).

7. Berganza, J. C., \& Broto, C. (2012). Flexible inflation targets, forex interventions and exchange rate volatility in emerging countries. Journal of International Money and Finance, 31(2), 428-444.

8. Yazid, A. S., \& Muda, M. S. (2006). The Role of Foreign Exchange Risk Management in Malaysia. Irish Journal of Management, 26(2).

9. Pritamani, M. D., Shome, D. K., \& Singal, V. (2004). Foreign exchange exposure of exporting and importing firms. Journal of Banking \& Finance, 28(7), 1697-1710.

10. Dash, M., \& NS, A. K. (2013). Exchange rate dynamics and Forex hedging strategies. Investment Management and Financial Innovations, 10(4).

11. Ho, K. W. (1993). Foreign exchange risk management: a survey of Singapore listed companies. Singapore Management Review, 15(2), 43-54.

12. Schanz, J. F. (2009). How do different models of foreign exchange settlement influence the risks and benefits of global liquidity management.

13. Belk, P. A. (2002). The organisation of foreign exchange risk management: a three-country study. Managerial Finance, 28(11), 43-52.

14. Hakkarainen, A., Joseph, N., Kasanen, E., \& Puttonen, V. (1998). The foreign exchange exposure management practices of Finnish industrial firms. Journal of International Financial Management \& Accounting, 9(1), 34-57.

15. Ahmed, H. A., \& Uddin, M. G. S. (2009). Export, imports, remittance and growth in Bangladesh: An empirical analysis. Trade and Development review, 2(2). 